\title{
Výzkum profesních hodnot u studentů učitelství 1. stupně ZŠ - výsledky smíšeného modelu výzkumu ${ }^{1}$
}

\author{
Research on professional values of primary student teachers ${ }^{6}-$ results of $^{-}$ \\ mixed model research
}

Tat'ána Göbelová

\begin{abstract}
Abstakt: Př́spěvek shrnuje výsledky studie sekvenčního smíšeného výzkumu profesních hodnot u studentů učitelství 1. stupně ZŠ Cílem projektu bylo: 1 analyzovat oblast profesních hodnot studenti̊ učitelství z hlediska intrinsických a extrinsických hodnot. 2 Zjistit názory studentů na nejdůležitější aspekty práce učitele. V kvantitativní části výzkumu byl testován a použit standardizovaný dotazník Work Values Inventoty (Super, 1970). Na základě analýzy dat vyplynulo, že studenti považují za nejdůležitější pracovní hodnoty dosažitelnost práce, altruismus a způsob života. Kvalitativní data byla shromážděna na pomocí metody CREDO MEM zjišt'ující názory studentů učitelství na nejdůležitější profesní hodnoty v práci učitele. Tato metoda byla doplněna hloubkovými rozhovory. Zdroje důležitosti práce učitele představují tyto kategorie: smysl, láska a vztah $k$ dětem, morální hodnoty, výchova a vzdělávání, profesní kompetence. Analýza získaných dat umožňuje porozumět hodnotovým strukturám $\mathrm{v}$ oblasti profesních hodnot studentů učitelství, přispívá k rozvoji jejich profesionality na strukturální úrovni (požadavky na profesní role), ale především na postojové úrovni (povolání k výkonu profese, studentovo sebepojetí).
\end{abstract}

Klíčová slova: profesní hodnoty, pracovní hodnoty, studenti učitelství 1. stupně ZŠ, extrinsické hodnoty, intrinsické hodnoty, dotazník WVI Work Values Inventory, metoda CREDO MEM.

\begin{abstract}
The aim of the paper is to analyse professional values among primary student teachers'. The objectives of the paper are to: 1. Analyse work values of these students in terms of extrinsic and intrinsic values; 2.Ascertain the students' views concerning the most important aspects of teacher's work. Design: Sequential mixed model research. Methods: In quantitative research data was collected using 45 questions (Work Values Inventory, D. Super, 1970). Qualitative research utilises methods of CREDO MEM as well as depth interview. Findings: 1. Achievement, altruism and way of life were found as three most important values in this research. 2. Open coding identified the importance of these source categories: meaning, love and relationship with the children, moral values, education, and professional competence. Conclusions: This research provides data concerning the values, motives and needs of teacher's student. This research can be used as a resource for self-reflection by student in building their professional identity on both - a structural and a attitudinal level.
\end{abstract}

Keywords: professional values, work values, primary student teachers', extrinsic values, intrinsic values, WVI Super's Work Values Inventory, CREDO MEM method

\footnotetext{
${ }^{1}$ Př́íspěvek je součástí výzkumného projektu SGS9/PdF/2010, zakázka 45/6104, zdroj 1610 Výzkum profesních hodnot u studentů učitelství 1. stupně a u učitelů 1. stupně ZŠ a výzkumného projektu APVV-0026-07 Profesia „učitel' preprimárnej edukácie“ a „učitel' primárnej edukácie“v dynamickom poňatí.
} 


\section{1 Úvod}

Hodnoty tvoří ústřední součástí kompetentní profesní praxe učitele (In Arthur, Davison, \& Lewis, 2005). Výzkum profesních hodnot jako preferencí, postojů, myšlenek a názorů, které ovlivňují chování, jednání a profesní volby v pedagogické praxi učitelů, patří neoddělitelně $\mathrm{k}$ problematice profesionalizace učitele.

\section{Teoretická východiska}

Pro potřeby výzkumu jsme vycházeli z pojetí pracovních a profesních hodnot, které vycházejí z obecných životních, tedy osobních hodnot jedince. Přes různé typologie pracovních hodnot představa „postoje vůči práci nebo orientaci v souvislosti s prací“ představuje centrální prvek všech interpretací. Pracovní hodnoty představují specifické cíle, které jednotlivec považuje za důležité a kterých se snaží v pracovním prostředí dosáhnout. $Z$ hlediska typologie pracovních hodnot rozlišujeme profesní hodnoty na intrinsické (vnější) a extrinsické (vnitřní) (Nord et al., 1990). Intrinsické pracovní hodnoty vyjadřují výsledky, kterých se dosahuje prací nebo při pracovních činnostech a které závisí na náplni práce. Intrinsické hodnoty jsou ty, které se týkají konkrétního zájmu nebo jsou měřítkem, jak práce přispívá společnosti Extrinsické hodnoty představují vnější znaky - vztahují k příznivým podmínkám, které jsou součástí práce, patří zde např. i potenciál výdělku a jiných vnějších znaků. (In Uçanok, 2008).

„Profesními hodnotami míníme jak složité soustavy přesvědčení, které by učitelé měli mít, to znamená, které jsou pro jejich profesi příslušné, přiměřené a spolehlivé, tak rovněž tímto pojmem označujeme kroky (činnosti, jednání), jimiž učitel tato svá přesvědčení přenáší na žáky.“ (Arthur, Davison, \& Lewis, 2005, s. 5). Zároveň profesní hodnoty jsou hodnoticími měřítky, podle kterých si lidé vykládají své pracovní zkušenosti a která určují význam, jaký jednotlivci přikládají práci, pracovním pozicím, organizacím, určitým událostem a podmínkám (In Uçanok, 2008).

\section{Metodologie}

\subsection{Výzkumný problém}

Analyzovat oblast profesních hodnot studentů učitelství a učitelů 1. stupně ZŠS.

Dílčí cíle výzkumu byly rozděleny do dvou kategorií:

1. Analyzovat pracovní hodnoty studentů učitelství z hlediska intrinsických a extrinsických kategorií hodnot. Navrhnout a testovat techniku dotazníku pro analýzu pracovních hodnot u studentů učitelství 1. stupně ZŠ a u učitelů 1. stupně ZŠ pro kategorii intrinsických a extrinsických hodnot.

2. Zjistit názory učitelů na nejdůležitější aspekty práce učitele. Navrhnout kvalitativní techniku otevřených výpovědí doplněnou technikou hloubkového interview pro studenty učitelství 1. stupně ZŠS.

\subsection{Model výzkumu}

Smíšený model výzkumu s využitím sekvenčně probíhající kvantitativní a kvalitativní fáze. 


\subsection{Výzkumné metody}

- standardizovaný dotazník Work Values Inventory -WVI (Super, 1970 a jeho modifikace)

- metoda CREDO MEM

- hloubkové rozhovory.

Pro účely analýzy dat dotazníkového šetření a testování validity a reliability dotazníku jsme využili následující testy: V rámci projektu byla zkoumána realiabilita dotazníku Super Work Values (vnitřní konzistence a reliabilita) pomocí Cronbach,s $\alpha$ testu. Faktorovou analýzou byly extrahovány 2 faktory (obrázek 1).

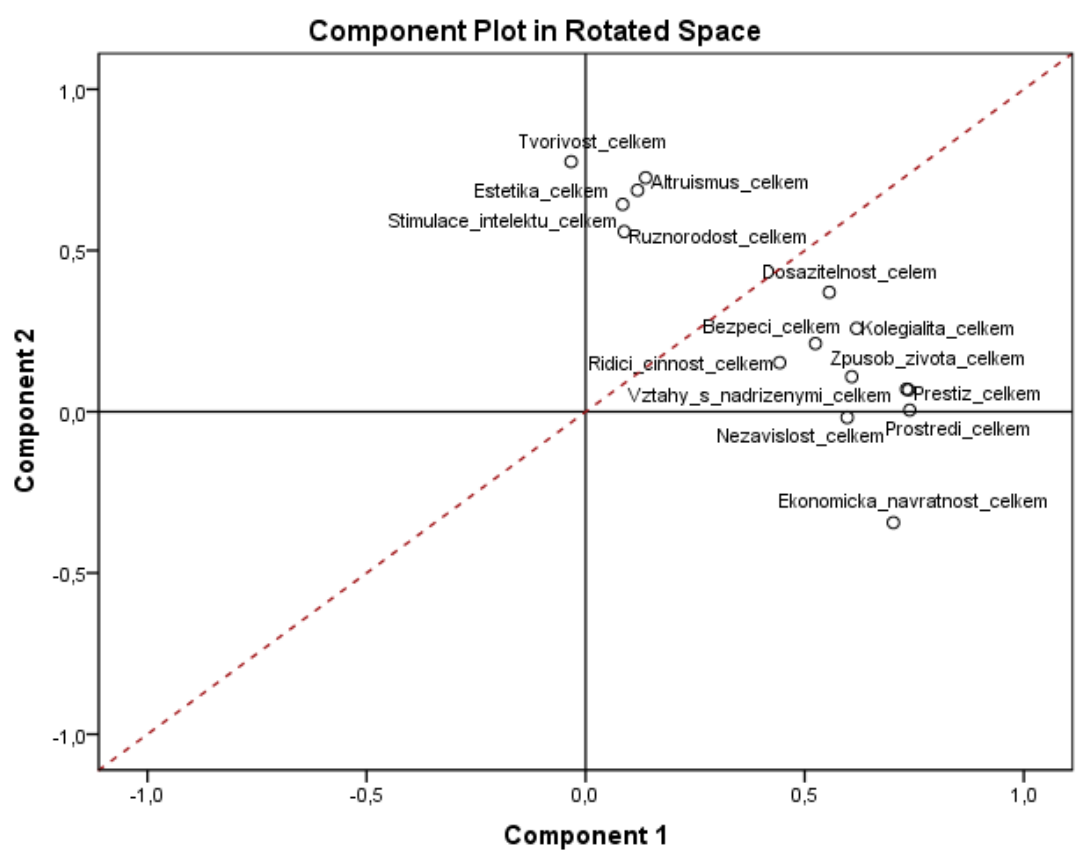

Obrázek 1. Faktorová analýza pro 2 faktory.

V obrázku jsou faktory odděleny referenční linií. První komponentu je možno chápat jako vnější, extrinsicky orientovanou, druhou pak jako orientovanou na vnitřní, intrinsickou oblast pracovních hodnot. U dvou faktorového modelu byla rovněž statisticky testována reliabilita pro oba faktory: extrinsický a intrinsický. Reliabilita intrisické faktoru - Cronbachovo $\alpha=$ 0,732, žádná položka nesnižuje reliabilitu (Cronbachovo $\alpha$ je vždy nižší než plná hodnota 0,732). Reliabilita extrinsického faktoru - Cronbachovo $\alpha=0,832$.

\subsection{Výzkumný vzorek}

Studenti oboru Učitelství 1. stupně ZŠ na Pedagogické fakultě Ostravské univerzity v Ostravě, 1., 2. a 4. ročník prezenčního (PS) a kombinovaného studia (KS). Celkem 114 respondentů, z toho 75 studentů prezenčního studia a 39 studentů kombinovaného studia (34 nekvalifikovaných a 5 kvalifikovaných učitelů). Metoda CREDO MEM - výzkumný soubor tvořilo celkem 84 studenti̊ 1., 2. a 4. ročníku PS a KS oboru Učitelství 1. stupně ZŠ. Hloubkové rozhovory - 3 studenti PS a 3 studenti KS. 


\section{Výsledky a diskuse}

\subsection{Výsledky kvantitativního šetreni}

Jako kvantitativní technika byl použit standardizovaný dotazník Work Values Inventory (Super, 1970) obsahující 15 typů pracovních hodnot obsažených ve 45 položkách. Respondenti u každé položky rozhodovali o míre důležitosti jednotlivých pracovních hodnot, posuzovací škála byla pětistupňová. Obrázek 2 zachycuje data jako výsledné skóry pro každou jednotlivou pracovní hodnotu.

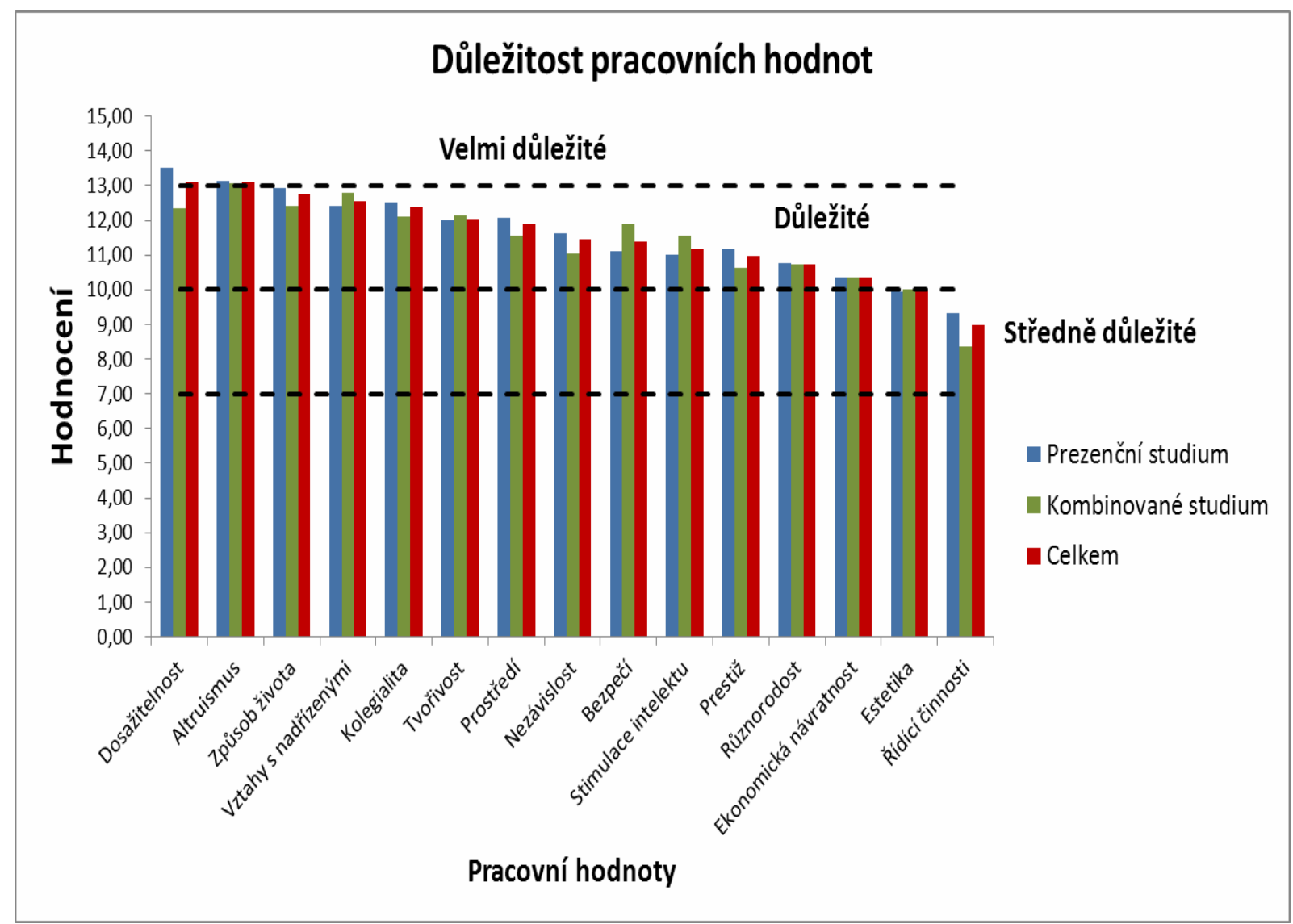

Obrázek 2. Důležitost pracovních hodnot

Na základě dvoufaktorové analýzy rozdělující pracovní hodnoty na intrinsické a extrinsické se jako velmi důležité pro studenty učitelství jeví extrinsická hodnota dosažitelnost (práce, která dává člověku pocit, že vykonal svou práci dobře), intrinsická hodnota altruismus (práce, která umožňuje člověku přispívat k lepšímu blahobytu ostatních) a následuje další extrinsická hodnota způsob života (práce, která dovoluje člověku žít takový způsob života, který si vybere a být takovým člověkem, kterým by chtěl být).

Z hlediska specifika pedagogické práce se zaměřme na pracovní hodnotu stimulaci intelektu (práce, která poskytuje př́ležitost nezávislému myšlení a učení, jak a proč věci fungují). Vzhledem k probíhající školské reformě a jejímu důrazu na rozvoj kritického myšlení a proaktivního učení by tato hodnota měla mít vysoké zastoupení. Jako velmi důležitou považuje stimulaci intelektu však pouze 25 respondentů. 
Další pracovní hodnota, kterou můžeme považovat za jednu ze stěžejních pro pedagogickou práci, je tvořivost (práce, která dovoluje člověku vytvářet nové věci, navrhovat nové výrobky). Za velmi důležitou ji pokládá 48 respondentů.

Estetika (práce, která umožňuje člověku vytvářet hezké věci a dávat světu něco krásného) jako pracovní hodnota je 9 studenty považována dokonce jako málo důležitá., pouze 12 studentů ji považuje jako velmi důležitou.

Zajímavý je výsledek důležitosti pracovní hodnoty ř́dicí činnost (práce, která umožňuje člověku plánovat a rozvrhovat práci ostatním). Z hlediska důležitosti ji respondenti zařadili jako nejméně důležitou hodnotu, což je překvapivé vzhledem ke specifičnosti učitelské profese - její nedílnou součástí je vést, rozvrhovat a facilitovat učební činnosti žáků. Jak vyplývá z obrázků, v pracovních hodnotách nejsou signifikantní rozdíly mezi studenty učitelství a nekvalifikovanými učiteli z pedagogické praxe.

\subsection{Výsledky kvalitativního šetření}

Pomocí kvalitativní techniky CREDO MEM (Kouzes,Poster, 1998 In Křivohlavý, 2006, s. 65) byl studentům zadáván písemný úkol: „Co si myslite, že je nejdůležitější v práci učitele?“ V této fázi výzkumu byly od dotazovaných 84 respondentů získány odpovědi na tuto otevřenou otázku. Tím se podařilo získat co nejbohatší a nejdetailnější vyjádření všeho, co studenti učitelství považují za nejdůležitější v práci učitele. Technika CREDO MEM byla u 6 studentů učitelství doplněna hloubkovým rozhovorem.

Pojem hodnoty subsumuje i ostatní pojmy, které pojednávají o dynamických a společenských vlastnostech člověka - jsou to např. cíle, preference, motivy, ideály. Na základě otevřeného kódování byly určeny tyto dimenze jako zdroje důležitosti v práci učitele:

- smysl („vidět smysl ve své práci; pro učitele je nejdůležitější, aby si uvědomil, proč svou práci dělá; nejdůležitější je touha a přesvědčení pomáhat a naučit; cítit svou práci jako poslání"),

- láska a vztah $k$ dětem („měl by být pozitivní, ohleduplný, laskavý; dobrý vztah k dětem, tolerantnost; empatie; schopnost naslouchat; umět se vcítit; vztah učitele založený na porozumění a důvěře; být připraven sdílet problémy“"),

- morální hodnoty (,,spravedlnost; obětavost; zodpovědnost"“),

- kreativita (,ve výuce využívat kreativitu a fantazii; umět improvizovat; být otevřený novým věcem; zkoušet nové věci a postupy ve výuce"),

- výchova, vzdělávání („naučit; předat vědomosti; rozvíjet osobnost; naučit základní dovednosti pro život"'),

- profesní kompetence „(být dobrým didaktikem; umět řešit výchovné situace; učit tak, aby děti látku zvládaly a rozuměly jí; mít dostatek vědomostí dovedností $\mathrm{k}$ výkonu profese").

Nejvyšší zastoupení v otevřených výpovědích studentů zaujímala kategorie smyslu a lásky a vztahu $k$ dètem, a to jak u studentů učitelství bez pedagogické praxe, tak i studentů $\mathrm{s}$ pedagogickou praxí - nekvalifikovaných učitelů. Z kvalitativnícho šetření vyplynulo, že pro respondenty z hlediska profesních hodnot jsou významné intrinsické (sebeaktualizačních) hodnoty. 


\section{Shrnutí}

Výzkumný problém směřoval $\mathrm{k}$ analýze pátého sít'ového rozměru nových učitelských rolí („Learning Teacher Network“) v oblasti ,zajištěni hodnot, vytvářeni vizi a odpovídajicích poslání učitelské profese“ (Rýdl, 2008). Z hlediska splněných dílčích cílů výzkumu byla přeložena a testována dotazníková technika pro analýzu pracovních hodnot u studenti̊ učitelství 1. stupně ZŠ pro kategorie intrinsických a extrinsických hodnot - Work Values Inventory (Super, 1970). Tato dotazníková technika doplněná kvalitativní technikou CREDO MEM a hloubkovými rozhovory zaměřenými na zdroje důležitosti v práci učitele umožní reflektovat jednotlivé profesní hodnoty u studentů učitelství. Výsledky výzkumu mohou přispět k rozvoji profesionality studentů učitelství na strukturální úrovni (požadavky na profesní role), ale především na postojové úrovni (povolání k výkonu profese, studentovo sebepojetí).

\section{Literatura}

Arthur, J., Davison, J., \& Lewis, M. (2005). Professional values in teaching and learning. New York: Routledge-Falmer.

Cakirpaloglu P. (2004). Psychologie hodnot. Praha: Votobia.

Harland, D. T., \& Pickering, N. (2011). Values in higher education teaching. New York: Routledge.

Hendl, J. (2005). Kvalitativní výzkum. Základní metody a aplikace. Praha: Portál.

Hendl, J. (2009). Přehled statistických metod. Analýza a metaanalýza dat. Praha: Portál.

Křivohlavý, J. (2006). Psychologie smysluplnosti existence. Praha: Grada.

Nord, W. R., Brief, A. P., Atieh, J. M., \& Dorethy, E. M. (1990). Studying mening of work. The case of work values. Lexington: Lexington Books.

Rýdl, K. (2008). Kvalita vzdělávání učitelů v Evropě. Standardizace nové role učitele? In Pedagogická evaluace 08 Sociália 2008 (pp. 2-8). Ostrava: Pdf OU.

Super, D. (1970). Manual work values inventory. Chicago: Riverside Publishing Co.

Uçanok, B. (2008). The effects of work values, work-value congruence and work centrality on organizational citizenship behavior. World Academy of Science, Engineering and Technology, 46, $156-167$.

Work importance profiler, v. 3.0. (2002). Dostupné z http://www.onetcenter.org/WIP.htmlsoftware

Zytowski, D. (Ed.). Supers work values inventory. Technical manual, version 1.2. Dostupné $\mathrm{z}$ http://www.kuder.com.

\section{Kontakt}

Mgr. Tat’ána Göbelová, Ph.D.

Ostravská univerzita

Pedagogická fakulta

Mlýnská 5, 71000 Ostrava 1

Tatana.Gobelova@osu.cz

\section{Bibliografické údaje}

Göbelová, T. (2011). Výzkum profesních hodnot u studentů učitelství 1. stupně ZŠ - výsledky smíšeného modelu výzkumu. In T. Janík, P. Knecht, \& S. Šebestová (Eds.), Smíšený design v pedagogickém výzkumu: Sborník př̀spěvků z 19. výroční konference České asociace pedagogického výzkumu (s. 292-297). Brno: Masarykova univerzita.

Dostupné z: http://www.ped.muni.cz/capv2011/sbornikprispevku/gobelova.pdf doi: 10.5817/PdF.P210-CAPV-2012-9 